\title{
КОМПЛЕКСНАЯ РЕКУЛЬТИВАЦИЯ ТЕРРИТОРИИ ПАВЕЛЬЦЕВСКОЙ НЕФТЕБАЗЫ
}

\author{
Островский Юрий Владимирович ${ }^{1,2}$, \\ ostrovskij@corp.nstu.ru, YuVOstrovskiy@aogspi.ru
}

\author{
Заборцев Григорий Михайлович ${ }^{2}$, \\ GMZaborcev@aogspi.ru \\ Черноок Владислав Анатольевич², \\ VAChernook@aogspi.ru \\ Крестинин Афанасий Александрович, \\ AAKrestinin@aogspi.ru \\ 1 Новосибирский государственный технический университет, \\ Россия, 630073, г. Новосибирск, пр. Карла Маркса, 20. \\ ${ }^{2}$ Новосибирский филиал АО «Государственный специализированный проектный институт», \\ Россия, 630075, г. Новосибирск, ул. Б. Хмельницкого, 2. \\ ${ }^{3}$ АО «Государственный специализированный проектный институт», \\ Россия, 115088, г. Москва, ул. Шарикоподшипниковская, 4, корп. 1А.
}

Актуальность. В геологическом строении исследованного участка в пределах глубины 20,0 м представлены четвертичные $\left(Q_{\|-1 /}\right)$ отложения: покровные, озерно-ледниковые, флювиогляциальные, песчано-глинистыми днепровско-московского межледниковья; моренные глинистые московской и днепровской стадий оледенения; флювиогляциальные пески окско-днепровского межледниковья. Данные грунты, слагающие площадку Павельцевской нефтебазы (г. Долгопрудный Московской обла(ти), работающей с 50-х гг. XX в., в той или иной мере загрязнены нефтепродуктами, а также тяжелыми металлами (свинец, медь, цинк, никель). Нефтепродукты в результате проливов просочились в грунт и достигли уровня грунтовых вод (5,5-6,5 м), образовав в зонах распространения линз и прослоев песчаных грунтов различной крупности в глинистой толще плавающие линзы из смеси бензина и дизельного топлива мощностью от 0,2 до 0,4 м. Обнаружено значительное загрязнение нефтепродуктами вод реки Безымянная, образующей перед впадением в Клязьминское водохранилище пруд, примыкающий к территории нефтебазы, что может быть связано с разгрузкой в пруд линз нефтепродуктов.

Цель: разработка оптимальной схемы рекультивации загрязненных нефтепродуктами четвертичных песчано-глинистых грунтов, слагающих площадку Павельцевской нефтебазы на основе результатов инженерно-геологических и инженерно-экологических изысканий, включая лабораторные геохимические исследования.

Методы: инженерно-геологические исследования грунтов - бурение скважин, лабораторные геоэкологические исследования проб грунтов, наблюдение за уровнем подземных вод, определение влияния биопрепаратов на деградацию нефтепродуктов и гуминовых препаратов на подвижность ионов тяжелых металлов в грунтах, грунтовых водах надморенного водоносного горизонта во флювиогляциальных пчано-глинистых отложениях днепровско-московского межледниковья и подземных водах подморенного (надъюрского) водоносного горизонта во флювиогляциальных песчаных отложениях окско-днепровского межледниковья.

Результаты. Предложена схема комплексной рекультивации загрязненных грунтов площадки Павельцевской нефтебазы, включающая откачку линз нефтепродуктов, иммобилизацию тяжелых металлов в грунтах с использованием гуминовых препаратов (препарат «Энерген Экстра»), деструкцию нефтепродуктов биопрепаратами («БИООЙЛ-АА» разработка ФБУН ГНЦ ВБ «Вектор» г. Новосибирск) и установку гидравлической завесы (дренажа). Реализация предложенной схемы позволит извлечь нефтепродукты, провести иммобилизацию тяжелых металлов в поверхностном слое грунта, резко снизить в нем содержание нефтепродуктов, существенно снизить поступление нефтепродуктов из зоны аэрации грунтов Павельцевской нефтебазы в пруд реки Безымянная в зоне разгрузки грунтовых вод.

\section{Ключевые слова:}

Нефтебаза, загрязнение грунтов, нефтепродукты, тяжёлые металлы, рекультивация, гуминовые препараты, биопрепараты, линзы нефтепродуктов, гидравлическая завеса.

\section{Введение}

Павельцевская нефтебаза (ЗАО «УниверсалНефть», г. Долгопрудный Московской обл.) была построена в 50-х гг. XX в. на левом берегу реки Клязьмы и имеет искусственную гавань, способную принимать нефтеналивные суда. Павельцевская нефтебаза до настоящего времени используется для снабжения светлыми нефтепродуктами (бензин и дизельное топливо) предприятий Подмо- сковья. Совокупный объем хранения нефтепродуктов достигает $180000 \mathrm{~m}^{3}$; это вторая по величине действующая нефтебаза Московской области.

Грунты площадки Павельцевской нефтебазы загрязнены нефтепродуктами в результате проливов во время перекачки при загрузке и разгрузке или в результате нарушений герметичности топливных танков, при этом в процессе инфильтрации нефтепродукты достигли уровня грунтовых 
вод, образовав на отдельных участках плавающие линзы.

В воде реки Безымянная, образующей перед впадением в Клязьминское водохранилище пруд, примыкающий к территории Павельцевской нефтебазы, обнаружено трехкратное превышение концентрации нефтепродуктов над нормативным.

Кроме нефтепродуктов в грунтах Павельцевской нефтебазы содержатся примеси тяжёлых металлов (свинца, меди, цинка, никеля, кадмия), которые попали в грунт с нефтепродуктами в качестве антидетонирующей присадки к моторному топливу (тетраэтилсвинец) или как их примеси.

Для рекультивации грунтов Павельцевской нефтебазы необходимо провести мероприятия по предотвращению миграции нефтепродуктов, тяжёлых металлов в грунтах, грунтовых и подземных водах, ликвидировать линзы нефтепродуктов, а также создать надежный заслон выносу нефтепродуктов грунтовыми водами в пруд реки Безымянная, примыкающий к территории нефтебазы, и далее в Клязьминское водохранилище.

Загрязнение грунтов площадки Павельцевской нефтебазы нефтепродуктами не является уникальным явлением. В настоящее время в нашей стране имеются обширные исследования по установлению степени загрязнения грунтов предприятий нефтедобычи, переработки и мест хранения нефтепродуктов, а также предложены методы борьбы с этими загрязнениями $[1,2]$.

Наиболее опасными из нефтепродуктов считаются плавающие линзы нефтепродуктов на поверхности грунтовых вод (мощностью до 1-3 м), которые могут захватывать значительные территории нефтебаз [2]. Удаление линз нефтепродуктов осуществляют методом откачки непосредственно из линзы или созданием гидравлической завесы [3]. Для очистки нефтезагрязненных грунтов широко применяется метод биоремедиации с использованием биопрепаратов [4-7].

Рекультивацию грунтов и грунтовых вод в некоторых случаях осуществляют методом самоочистки [8], но это требует прекращения производственной деятельности на данной территории и ее вывода на длительное время (20-30 лет) из народнохозяйственного оборота.

\section{Геологическое строение грунтов \\ Павельцевской нефтебазы}

В результате инженерно-геологических изысканий (геологическое строение грунтов, гидрогеологические условия), выполненных отделом комплексных инженерных изысканий АО «ГСПИ» (г. Москва) установлено, что для района в границах площадки Павельцевской нефтебазы в пределах исследованной глубины 20,0 м характерно распространение четвертичных $\left(\mathrm{Q}_{\mathrm{II}-\mathrm{IV}}\right)$ песчано-глинистых отложений, представленных техногенными, покровными, флювиогляциальными, озёрноледниковыми и моренными суглинками с линзами и прослоями песков различной крупности общей мощностью толщи 16,0-16,5 м, которые подстилаются песчаными отложениями окско- днепровского межледниковья, насыщенными водой. Инженерно-геологические изыскания выполнены АО «Государственный специализированный проектный институт» (г. Москва).

В пределах площадки нефтебазы четвертичные отложения представлены:

- насыпными техногенными грунтами ( $\left.\mathrm{t} \mathrm{Q}_{\mathrm{IV}}\right)$, образованными при планировке площадки: суглинком туго- и мягкопластичным, с включением строительного мусора, мощность слоя 2,0-4,0 м;

- покровными отложениями $\left(\mathrm{prQ}_{\mathrm{III}}\right)$ : суглинком тяжелым пылеватым, редко песчанистым (местами глиной легкой пылеватой) тугопластичным, участками полутвердый, коричневый, мощность слоя составляет 1,0-2,0 м;

- моренными отложениями Московской стадии оледенения ( $\left.\mathrm{gQ}_{\mathrm{II}}^{\mathrm{ms}}\right)$ : суглинками лёгкими песчанистыми, от мягкопластичных до полутвёрдых, с включением гравия, гальки, редко валунов изверженных и осадочных пород до 20-25\%, которые распространены на участках с высокими отметками поверхности земли, мощность слоя 2,0-4,0 м;

- флювиогляциальными отложениями одинцовского межледниковья (fQ $\left.{ }_{\text {II }}^{\mathrm{dn}-\mathrm{m} s}\right)$, распространёнными повсеместно: полутвердыми, текуче-пластичными суглинками, песками мелкими, средней крупности и гравелистыми, общей мощностью толщи 5,0-7,0 м;

- моренными отложениями Днепровской стадии оледенения $\left(\mathrm{gQ}_{\mathrm{II}}^{\mathrm{dn}}\right)$ : суглинками лёгкими песчанистыми, от тугопластичных до полутвёрдых, с включением гравия, гальки, редко валунов изверженных и осадочных пород до $10-15 \%$, распространеных повсеместно, мощность слоя 4,0-6,0 м;

- флювиогляциальными песчано-глинистыми отложениями окско- днепровского межледниковья $\left(\mathrm{fQ}_{\mathrm{II}}{ }^{\mathrm{ok}-\mathrm{dn}}\right)$ : суглинками мягкопластичными и песками мелкими, насыщенными водой, мощностью слоя 2,0-3,0 м.

Мощность толщи комплекса четвертичных отложений достигает 15-20 м.

\section{Гидрогеологические условия}

По возрасту и литологическому составу водовмещающих пород в пределах района выделяются два основных комплекса подземных вод, относящихся к четвертичным отложениям.

Водоносный комплекс подземных вод в четвертичных отложениях подразделяется на два горизонта. Первый горизонт - надморенный (водовмещающими грунтами являются песчано-глинистые отложения одинцовского межледниковья, водоупором - моренные глинистые отложения днепровской стадии оледенения). Горизонт безнапорный на участках распространения отложений московской морены обладает местным напором до 1-2 м, уровень вод залегает на глубине 3-4 м. 
Второй горизонт - подморенный (надъюрский), относящийся к песчано-глинистым флювиогляциальным отложениям окско-днепровского межледниковья, вскрывается на глубине 11-15 м, горизонт напорный, пьезометрический уровень устанавливается на глубине 6-8 м, величина напора составляет 5-7 м.

\section{Загрязнение грунтов Павельцевской нефтебазы}

Методологической основой для проведенных исследований по оценке уровня загрязнения нефтепродуктами грунтов и подземных вод, а также санации территорий являлись работы В.М. Гольдберга [3] и В.В. Середина [9].

Главный принцип, из которого исходили при разработке мероприятий по ликвидации последствий загрязнения почв нефтепродуктами и тяжелыми металлами - не нанести экосистеле больший вред, чем тот, который уже нанесен при загрязнении.

Содержание нефтепродуктов в грунтах определяли по ПНД Ф 16.1.41-04 [10]. Определение тяжелых металлов проводили по методикам фотометрического анализа, а также на атомно-эмиссионном спектрометре с индуктивной связанной плазмой iCAP 6300 Duo (Thermo Scientific, США), предназначенном для проведения качественного, полуколичественного и количественного элементного анализа самых разнообразных объектов.

Для биоремедиации грунтов, загрязненных нефтепродуктами, использовали биопрепарат «БИООЙЛ-АА», разработанный ФБУН ГНЦ ВБ «Вектор», г. Новосибирск.

Препарат представляет собой смесь культур микроорганизмов Acinetobacter, Enterobacter, Bacillus, активно катаболизирующих длинноцепочечные предельные углеводороды и находящихся в лиофилизированном (высушенном) состоянии. Количество жизнеспособных бактериальных клеток в 1 грамм - не менее $1,0 \cdot 10^{8}$.

Скорость переработки (разложения) нестепродуктов в грунтах биопрепаратом рассчитывали по формуле:

$$
W=\frac{m_{\text {н/п }}}{m_{\text {БП }} \cdot \tau},
$$

где $W$ - скорость переработки нефтепродуктов, $\Gamma / \Gamma$ суски; $m_{\text {н/п }}$ - масса переработанных нефтепродуктов, г; $m_{\text {вп }}$ масса внесенных биопрепаратов, г; $\tau$ - время обработки, сутки.

\section{Результаты и их обсуждение}

Типичный вид грунтов территории Павельцевской нефтебазы представлен на инженерно-геологическом разрезе (рис. 1).

Питание горизонта грунтовых вод осуществляется за счет инфильтрации атмосферных осадков. Грунтовые воды располагаются на глубине 5,5-6,5 м. В периоды весеннего снеготаяния и осенних затяжных дождей возможен подъем уровня подземных вод на 1,0 м.
Подземные воды подморенного водоносного горизонта напорные. Верхним водоупором служат моренные суглинки тугопластичные (по данным обследования Павельцевской нефтебазы в 2014 г.).

На большом участке размыва моренных отложений происходит объединение вод двух горизонтов: грунтового и подморенного. Общее направление потока грунтовых вод с севера на юг.

Линзы нефтепродуктов, локализованные на участках распространения песчаного грунта различной крупности, местами крупнообломочного щебенистого грунта с песчаным заполнителем, содержат смесь бензина и дизельного топлива.

В зоне аэрации грунтов Павельцевской нефтебазы вследствие длительного (более 50 лет) нахождения нефтепродуктов, в частности дизельного топлива, содержащего смесь углеводородов с температурой кипения $200-350{ }^{\circ} \mathrm{C}$, происходит постепенное накопление смолисто-асфальтеновых фракций - продуктов биодеградации этих нефтепродуктов [11]. Поэтому нефтепродукты в грунтах Павельцевской нефтебазы, вероятно, представлены не исходными летучими светлыми нефтепродуктами (бензин, дизельное топливо), а высокомолекулярными высококипящими углеводородами.

Содержание нефтепродуктов в поверхностном слое грунта Павельцевской нефтебазы изменяется от 60 до 5015 мг/кг (среднее содержание 1253 мг/кг), а на глубине в суглинках - от 520 до 3460 мг/кг (среднее содержание 1816 мг/кг). Таким образом, грунты Павельцевской нефтебазы по уровню загрязнения почв нефтепродуктами относятся в основном к слабо- или условно загрязненным почвам, и только отдельные участки - к высокозагрязненным [12].

Распределение нефтепродуктов по глубине грунтов площадки нефтебазы представлено на рис. 2. Данное распределение нефтепродуктов по классификации В.В. Середина [9] относится к первому типу. Уменьшение концентрации нефтепродуктов с увеличением глубины обусловлено капиллярным поднятием углеводородов к земной поверхности по мелким порам грунтов, представленных преимущественно суглинками.

Распределение нефтепродуктов в грунтах по глубине на площадке Павельцевской нефтебазы может быть описано уравнением:

$$
C=1692,08-295,39 h \text { при } R=-0,455 \text {, }
$$

где $C$ - концентрация нефтепродуктов в грунте, мг/кг; $h$ - глубина отбора образца грунта, м.

Распределение тяжелых металлов (свинец медь, цинк, никель) в грунтах на площадке Павельцевской нефтебазы (рис. 3) по классификации B.B. Середина относится к третьему типу - хаотичному изменению содержания по глубине [9]. Такое распределение обусловлено, вероятно, сорбцией тяжёлых металлов на грунтах $[13,14]$.

Препараты, используемые для ремедиации почв, можно условно разделить на две группы. Первая группа - препараты, которые обеспечивают иммобилизацию (снижение подвижности) пол- 


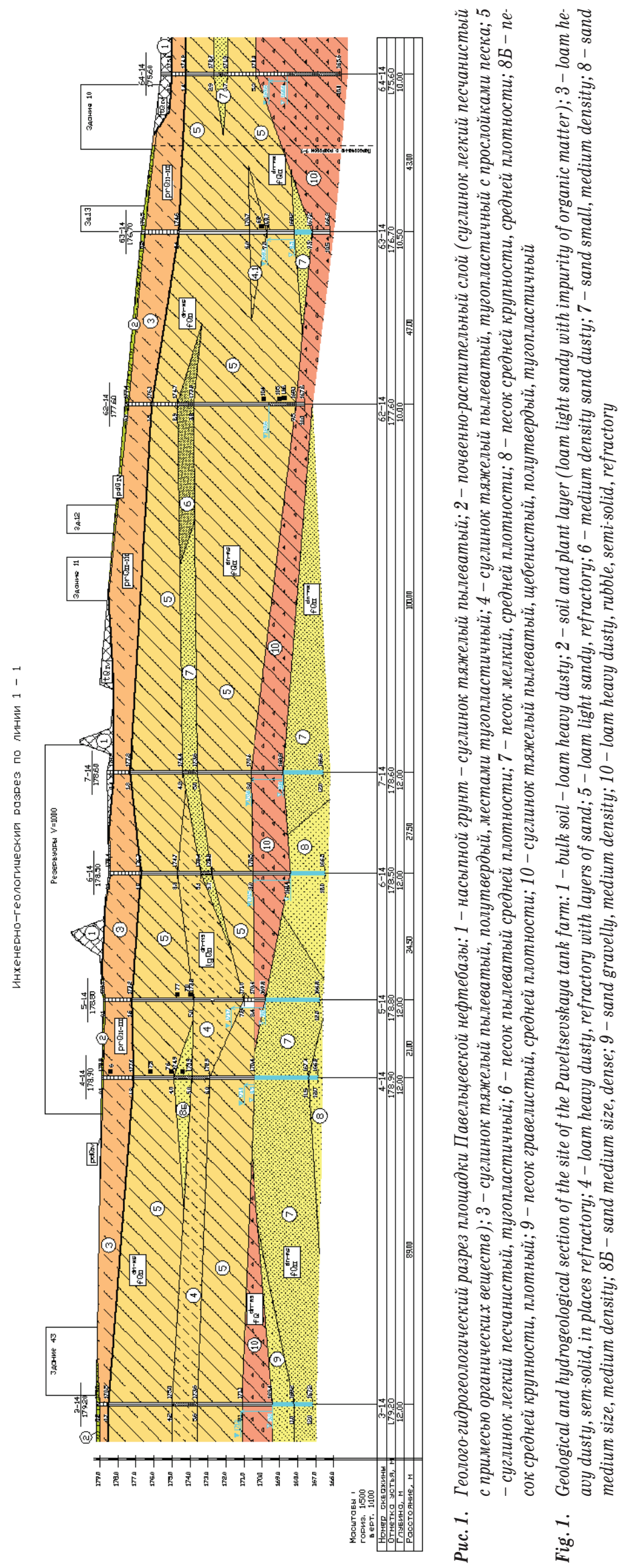


лютантов, тяжелых металлов в грунтах (например, гуминовые препараты, полученные из бурого угля или торфа) [15]. Ко второй группе относятся препараты, которые обеспечивают биоремедиацию грунтов - очистку от нефтепродуктов за счет дополнительно внесенных в почву микроорганизмов и активизации питательными субстратами аборигенной почвенной микрофлоры $[4,16,17]$.

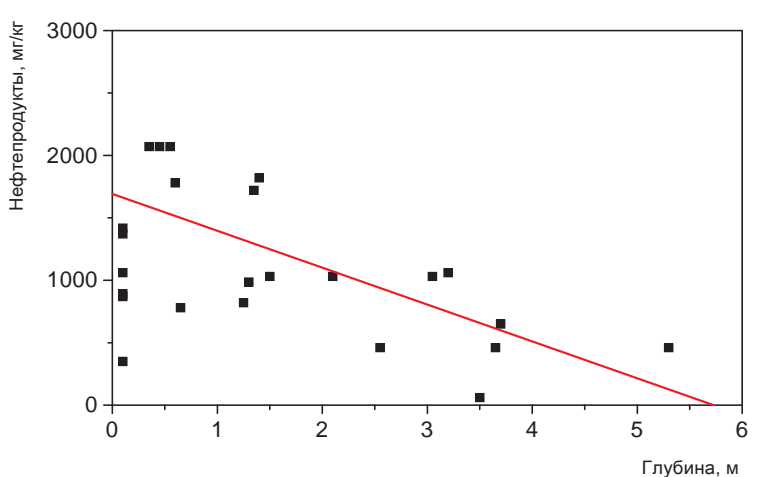

Pис. 2. Распределение нефтепродуктов в грунтах по глубине на плошадке нефтебазы

Fig. 2. Depth distribution of oil products in subsoil within the tank farm territory

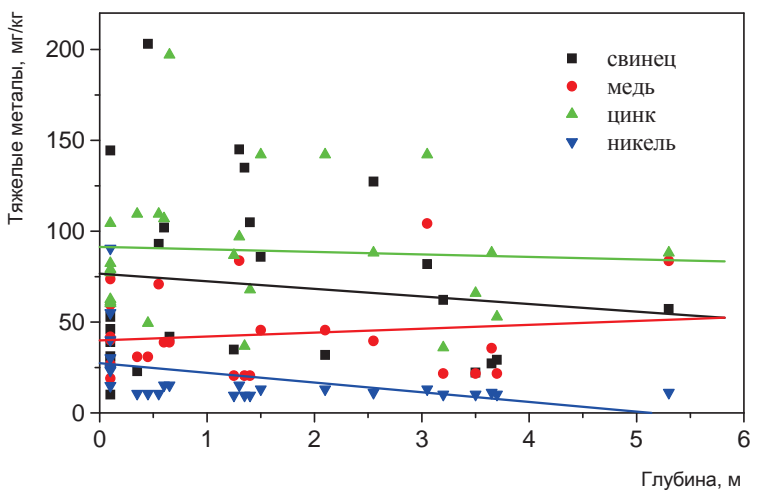

Рис. 3. Распределение тяжёльх металлов в грунтах по глубине на плошадке нефтебазы

Fig. 3. Depth distribution of heavy metals in subsoil within the tank farm territory

К ним можно отнести все известные отечественные препараты-биодеструкторы нефтепродуктов «Путидойл», «Дестройл», «Родер», «Универсал», «Биоойл» и др. [5].

\section{Обработка грунтов гуминовыми препаратами}

Концентрации тяжёлых металлов в грунтах площадки Павельцевской нефтебазы многократно превышают ПДК (ГН 2.1.7.2041-06) в почве, однако очистка этих грунтов от металлов традиционным методом (промывка грунтов) нецелесообразна по экономическим и экологическим соображениям, поскольку приводит к дополнительному загрязнению почвы промывными реагентами.

Более предпочтительно в данном случае связывание загрязняющих веществ в нерастворимые со- единения, что широко используется при обращении с грунтами, загрязненными тяжелыми металлами [18-20].

Гуминовые препараты являются естественными для окружающей среды, не образуют токсичных соединений в почве и воде, не загрязняют атмосферу, не оказывают негативного влияния на флору, фауну и биогеоценозы в целом, даже при использовании высоких доз [21].

Внесение гуминовых препаратов в грунты, загрязненные тяжёлыми металлами (цинк, свинец, никель, медь и др.), обеспечивает связывание их токсичных форм в безопасные нерастворимые металлоорганические комплексы, устойчивые длительное время в широком диапазоне рН [22-28]. Полученные комплексы практически не обладают подвижностью и способностью к миграции: их коэффициент фильтрации не превышает $10^{-8}-10^{-9} \mathrm{M} /$ сутки, что намного меньше коэффициентов фильтрации суглинков $\left(1 \cdot 10^{-2}-5 \cdot 10^{-2} \mathrm{M} /\right.$ сутки $)$ [22].

Распространение гуминовых препаратов по всему слою грунта осуществляется благодаря инфильтрации атмосферных осадков.

Пропитка суглинка (модели основной части грунта площадки Павельцевской нефтебазы), загрязненного тяжёлыми металлами $(\mathrm{Pb}, \mathrm{Cu}, \mathrm{Zn}$, $\mathrm{Ni}$, , 0,06 \%-м раствором гумата калия (был использован гуминовый препарат «Энерген Экстра» ЗАО «ТПК Техноэкспорт») при соотношении (масс.) гумат калия/тяжелые металлы=2,5-3,0:1 приводит к полной иммобилизации тяжелых металлов в суглинке, что связано, вероятно, с образованием нерастворимых соединений свинца, меди, цинка и никеля с гуминовыми кислотами.

Кроме иммобилизации тяжелых металлов гуминовые препараты улучшают структуру почвы, увеличивают её влагоемкость, улучшают газообмен, то есть проявляют свойства мелиорантов [29]. Благодаря редокс-медиаторным свойствам гуминовых веществ, содержащихся в гуминовых препаратах, ускоряются процессы анаэробного разложения органических веществ, загрязняющих почвы [30].

\section{Биоремедиация грунтов, загрязненных нефтепродуктами}

В экспериментах по разложению нефтепродуктов биодеструкторами в качестве модельных грунтов использовали: почву (модель насыпного поверхностного слоя грунта площадки нефтебазы), суглинок (модель основной части грунта) и песок (модель проницаемых включений в грунте).

Грунты были загрязнены аналогом смолистоасфальтеновых фракций грунта, в качестве которого использовали термостойкое минеральное компрессорное масло марки К-19 (ГОСТ 1861-73), кинематическая вязкость которого составляет 17-21 $\mathrm{Mм}^{2} / \mathrm{c}$ (при $\left.100{ }^{\circ} \mathrm{C}\right)$. Компрессорное масло К-19 ( $\rho=0,885$ г/мл) получено из малосернистой нефти, содержит высокомолекулярные углеводороды, но не содержит присадок и имеет высокую 
термоокислительную стабильность (работает при температуре до $\left.160^{\circ} \mathrm{C}\right)$.

Для разложения компрессорного масла К-19 использовали «Биоойл-АА» - биопрепарат для рекультивации нефтезагрязненных почв. Используемая форма препарата - 0,5\% раствор сухого порошка «Биоойл-АА». Раствор готовился непосредственно перед экспериментом, эксперименты проводили при температуре $t=18-20{ }^{\circ} \mathrm{C}$ и влажности грунтов не менее 40-50\% .

Результаты экспериментов при добавке биопрепарата «Биоойл-АА» в количестве 0,1 г/кг грунта представлены на рис. 4,5 .

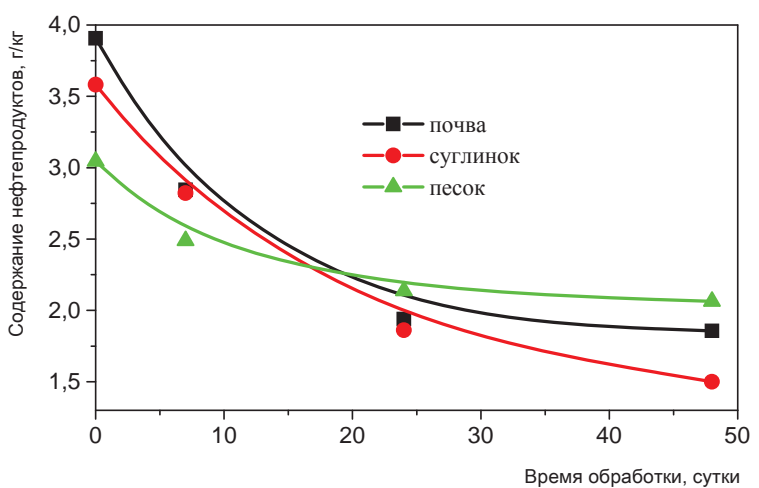

Puc.4. Содержание нефтепродуктов (компрессорное масло K-19) в грунтах в процессе их ремедиации биопрепаратол «Биоойл-AA»

Fig. 4. Content of petroleum products (compressor oil K-19) in soils at their remediation with biopreparation "Biooil-AA»

За 48 суток произошло двукратное снижение содержания нефтепродуктов в почве и суглинке. При обработке биопрепаратом «Биоойл-АА» почвы и суглинка, загрязненных минеральным маслом, эффективность биоремедиации более высокая, чем при обработке песка, что, вероятно, обусловлено присутствием в почве и суглинке аборигенной углеводородокисляющей микрофлоры, способной к окислению нефтепродуктов [31].

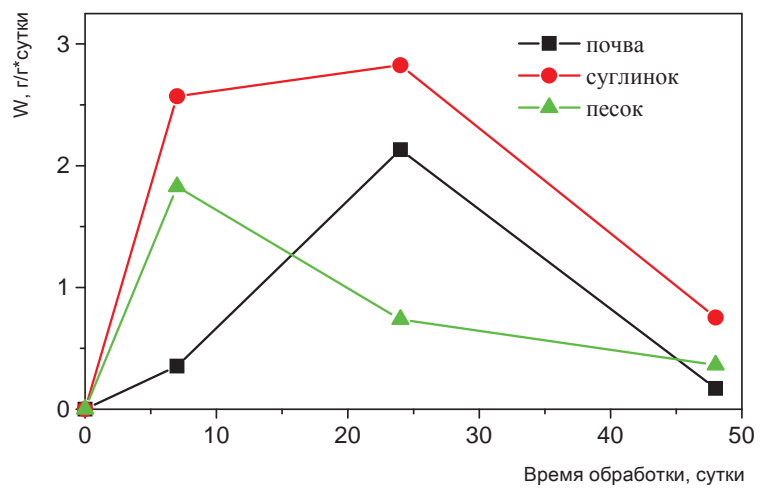

Puc. 5. Скорость биодеструкиии нефтепродуктов (компрессорное масло $K-19$ ) в грунтах биопрепаратом «Биоойл-АА»

Fig. 5. Speed of biodegradation of petroleum products (compressor oil K-19) in soils with biopreparation «Biooil-AA»

\section{Миграция нефтепродуктов из загрязненного грунта в очищенный}

После обработки биопрепаратом поверхностного слоя грунта, загрязненного нефтепродуктами, возникает градиент концентраций нефтепродуктов между верхним (очищенным) и нижним (загрязненным) слоями грунта, что способствует миграции нефтепродуктов под действием капиллярных сил. В работе [32] установлена восходящая миграция нефтепродуктов в слой экранирующего грунта за счет капиллярного поднятии.

Для оценки скорости подъема нефтепродуктов после очистки поверхностного слоя грунта и определения периодичности обработки грунтов биопрепаратом проведены эксперименты, в которых изучали скорость подъема уровня нефтепродукта (компрессорного масла $\mathrm{K}-19, \rho=0,885$ г/мл) по экранирующему грунту - суглинку, который моделирует грунты площадки Павельцевской нестебазы.

Массоперенос компрессорного масла К-19 при загрязнении суглинка изучали на модельных системах, в которых уплотненный чистый воздушносухой суглинок контактировал со слоем суглинка, искусственно загрязненного компрессорным маслом К-19 (10-50\% об.), а также дополнительно увлажненного дистиллированной водой (увлажнение $100 \%$ об.). Контактирующие слои суглинка выдерживали в стеклянных колоннах-лизиметрах при комнатной температуре в течение двух месяцев. Уровень подъема компрессорного масла К-19 фиксировали визуально.

Установлено, что скорость подъема компрессорного масла К-19 в слое суглинка в этих условиях не превышает 4,3 cм/год. Повышение влагосодержания грунта способствует увеличению скорости массопереноса компрессорного масла К-19 до 32,4 см/год, что согласуется с данными, полученными в работе [32].

\section{Схема комплексной рекультивации загрязненных грунтов Павельцевской нефтебазы}

Одним из первоочередных природоохранных мероприятий при рекультивации грунтов нефтебаз считается ликвидация «плавающей» линзы жидких нефтепродуктов посредством их извлечения методом откачки. Извлеченные нефтепродукты могут компенсировать часть затрат на проведение рекультивационных работ [4].

Удаление остаточных нефтепродуктов из геологической среды может продолжаться длительное время - десятки лет [9]. В этой связи реальным является постоянная локализация очага загрязнения. Для предотвращения поступления нефтепродуктов в гидрографическую сеть необходимо создать гидравлическую завесу (дренажную систему) в зоне разгрузки грунтовых вод.

Таким образом, предлагается следующая последовательность технологических операций по рекультивации грунтов Павельцевской нефтеба- 
зы, загрязненных нефтепродуктами и тяжелыми металлами:

- 1 этап - откачка линз нефтепродуктов с поверхности грунтовых вод;

- 2 этап - обработка поверхностного слоя грунта гуминовыми препаратами для иммобилизации тяжелых металлов, содержащихся в грунте;

- 3 этап - обработка поверхностного слоя грунта биопрепаратом, предназначенным для биоразложения нефтепродуктов (например, биопрепаратом «Биоойл-АА»;

- 4 этап - размещение гидравлической завесы из откачных скважин (дренажная система) в зоне разгрузки грунтовых вод.

\section{СПИСОК ЛИТЕРАТУРЫ}

1. Закруткин В.Е., Холодков Ю.И., Подольский А.Д. Экологические последствия эксплуатации нефтехранилищ в междуречье рек Дон и Сал // Геоэкология. Инженерная геология. Гидрогеология. Геокриология. - 2007. - № 6. - С. 506-517.

2. Чепрасова А.С. Гидрогеологические условия формирования нефтяного загрязнения в приустьевой части долины реки Туапсе (Северный Кавказ) и пути улучшения экологического состояния геологической среды: автореф. дис. ... канд. геол.минерал. наук. - Томск, 2012. - 21 с.

3. Гольдберг В.М., Газда С. Гидрогеологические основы охраны подземных вод от загрязнения. - М.: Недра, 1984. - 262 с.

4. Кирий 0.А. Экологическая оценка использования углеводородокисляющих бактерий при биоремедиации нефтезагрязненных почв и вод на юге России: автореф. дис. ... канд. биологич. наук. - Ростов-на-Дону, 2013. - 20 с.

5. Чачина С.Б., Болтунова С.В., Черкашина Н.В. Деструкция углеводородов нефти с использованием микробиологических препаратов «Байкал-Эм», «Тамир», «Восток» // Омский научный вестник. - 2015. - № 1. - С. 221-225.

6. Чачина С.Б., Лапочкин А.С. Влияние микробиологических препаратов «Байкал Эм 1», «Тамир» и «Восток» на выживаемость и численность дождевых червей Eisenia fetida при загрязнении почвы высокими концентрациями нефти // Международный журнал прикладных и фундаментальных исследований. - 2016. - № 6-3. - С. 512-514.

7. Сваровская Л.И., Алтунина Л.К., Ельчанинова Е.А. Биодеструкция ароматических соединений нефти, загрязняющей почву // Защита окружающей среды в нефтегазовом комплексе. -2015 . - № 1. - С. 7-11.

8. Кржиж Л., Пашковский И.С. Нефтезагрязненные подземные воды: санация или самоочистка? // Экология производства. 2007. - № 12. - С. 50-53.

9. Середин В.В. Санация территорий, загрязненных нефтью и нефтепродуктами // Геоэкология. - 2000. - № 6. - С. 525-540.

10. ПНД Ф 16.1.41-04. Количественный химический анализ почв. Методика выполнения измерений массовой концентрации нефтепродуктов в пробах почв гравиметрическим методом. М: Изд-во МПР РФ, 2004. - 13 с.

11. Одинцова Т.А. Разработка технологии идентификации и мониторинга нефтяных загрязнений: дис. ... канд. техн. наук. Пермь, 2010. - 214 c.

12. Методические рекомендации по выявлению деградированных и загрязненных земель (Утв. Роскомземом 28.12.1994, Минсельхозпродом РФ 26.01.1995, Минприроды РФ 15.01.1995).

13. Сиромля Т.И. Формы соединений свинца, кадмия и цинка в почва юга Западной Сибири // ВЕСТНИК Оренбургского государственного университета. - 2017. - № 12. - С. 26-29.

\section{Заключение}

В результате реализации предложенной схемы рекультивации грунтов площадки Павельцевской нефтебазы будут откачены нефтепродукты из линз, расположенных на поверхности грунтовых вод (уровень грунтовых вод 5,5-6,5 м), проведена иммобилизация тяжелых металлов в поверхностном слое грунта, что позволит прекратить их миграцию в грунтовые воды, будет резко снижено содержание нефтепродуктов в поверхностном слое грунта за счет биоразложения, прекращено поступление нефтепродуктов из зоны аэрации грунтов Павельцевской нефтебазы в пруд реки Безымянная в зоне разгрузки грунтовых вод.

14. Семенков И.Н. Формы нахождения металлов в суглинистых тундровых, таежных, подтаежных и лесостепных почвенногеохимических катенах: автореф. дис. ... канд. геогр. наук. M., 2016. -24 c.

15. Ганеев И.Г., Кулагин А.А. Ремедиация и рекультивация техногенно деградированных земель // ВЕСТНИК Оренбургского госуниверситета. - 2009. - № 6. - С. 554-557.

16. Enhanced remediation of hydrocarbon contaminated desert soil fertilized with organic carbons / S.S. Radwan, D. Al-Mailem, I. El-Nemr, S. Salamah // International Biodeterioration \& Biodegradation. - 2000, - V. 46. - № 2. - P. 129-132.

17. Bioremediation of a crude-oil polluted agricultural-soil at Port Harcourt, Nigeria / M.J. Ayotamuno, R.B. Kogbara, S.0.T. Ogaji, S.D. Probert // Applied Energy. - 2006. - V. 83. - № 11. P. 1249-1257.

18. Stevenson F.J. Organic matter reactions involving metal ions in soil. Ch. 16 // Humus Chemistry: Genesis, Composition and Reactions. $2^{\text {nd }}$ ed. - New York: John Wiley \& Sons, 1994.

19. Investigation of humic acid complexation behavior with uranyl ions using modified synthetic and natural humic acids / S. Pompe, K. Schmeide, M. Bubner, G. Geipel, K.H. Heise, G. Bernhard, H. Nitsche // Radiochimica Acta. - 2000, - V. 88, - P. 553-558.

20. Kim J.I., Czerwinski K.R. Complexation of Metal Ions with Humic Acid: Metal Ion Charge Neutralization Model // Radiochimica Acta. - 1996. - V. 73. - P. 5-10.

21. Stevenson F.J. Humus Chemistry. $1^{\text {st }}$ ed. - New York: John Wiley \& Sons, 1982

22. Огняник Н.С., Парамонова Н.К., Брикс А.Л. Основы изучения загрязнения геологической среды легкими нефтепродуктами. - Киев: АПН, 2006. - 278 с.

23. Gaffney J.S., Marley N.A., Clark S.B. Humic and Fulvic Acids. Isolation, Structure, and Environmental Role // ACS Symposium Series 651. - Washington, DC: American Chemical Society, 2-16 1996.

24. An Introduction to Humic Substances in Soil, Sediment and Water / G.R. Aiken, D.M. McKnight, R.L. Werhaw, P. MacCarthy // Humic Substances in Soil, Sediment and Water. - USA: John Wiley \& Sons, 1985.

25. Synthesis and characterization of humic acids with specific functional properties / S. Sachs, K. Schmeide, V. Brendler, A. Křepelová, J. Mibus, G. Geipel, K.-H. Heise, G. Bernhard // Investigation of the Complexation and the Migration of Actinides and Nonradioactive Substances with Humic Acids under Geogenic Conditions: Complexation of Humic Acids with Actinides in the 0xidation State IV Th, U, Np. Forschungszentrum Rossendorf, Institute of Radiochemistry, Wissenschaftlich-Technische Berichte. FZR 399, 2004. - P. 3-19.

26. The Impact of Humic Substances as Remediation Agents to the Speciation Forms of Metals in Soil / J. Burlakovs, M. Klavins, 
L. Osinska, 0. Purmalis // APCBEE Procedia 5. - 2013. P. $192-196$.

27. Kaschl A., Chen Y. Interactions of Humic Substances with Trace Metals and Their Stimulatory Effects on Plant Growth technology // Use of Humic Substances to Remediate Polluted Environments: From Theory to Practice. - Netherlands: Springer, 2005. P. 83-113.

28. Использование углегуминовых препаратов для локализации урана и ртути в жидких и твердых производственных отходах предприятий ГК «РОСАТОМ» / Ю.В. Островский, Г.М. Заборцев, В.В. Цивелёв, А.В. Бабушкин, Д.Ю. Островский, Н.Б. Егоров, С.Н. Чегринцев // Химия в интересах устойчивого развития. - 2016. - Т. 24. - № 6. - С. 781-787.

29. Гречищева Н.Ю., Перминова И.В., Мещеряков С.В. Перспективность применения гуминовых веществ в технологиях очистки нефтезагрязненных почв // Экология и промышленность России. - 2016. - № 1. - С. 30-36.

30. Humic substances as electron acceptors for microbial respiration / D.R. Lovley, J.D. Coates, E.L. Blunt-Harris, E.J.P. Phillips, J.C. Woodward // Nature. - 1996. - № 382. - P. 445-448.

31. Журавлева А.С., Лабутова Н.М., Андронов Е.Е. Влияние нефтезагрязнения на микробоценоз почв, прилегающих к нефтехранилищу // Экологическая генетика. - 2017. - Т. 15. № 1. - С.60-68.

32. Миграция нефтепродуктов из загрязненной почвы в насыпной изолирующий слой чистого песка / Е.Н. Федосеева, А.Д. Зорин, В.Ф. Занозина, Л.Е. Самсонова // Химия в интересах устойчивого развития. - 2014. - Т. 22. - № 5. - С. 497-503.

Поступила 27.06.2018 2.

\section{Информация об авторах}

Островский Ю.В., доктор технических наук, профессор Новосибирского государственного технического университета; начальник научно-исследовательского отдела Новосибирского филиала АО «Государственный специализированный проектный институт» .

Забориев Г.М., кандидат химических наук, начальник лаборатории научно-исследовательского отдела Новосибирского филиала АО «Государственный специализированный проектный институт».

Черноок В.A., директор Новосибирского филиала АО «Государственный специализированный проектный институт».

Крестинин A.A., начальник отдела комплексных инженерных изысканий $\mathrm{A0}$ «осударственный специализированный проектный институт». 
UDC 504.064.47

\title{
COMPREHENSIVE RECULTIVATION OF SOILS OF THE PAVELTSEVSKAYA TANK FARM
}

Yury V. Ostrovsky ${ }^{1,2}$,

ostrovskij@corp.nstu.ru, YuVOstrovskiy@aogspi.ru

\section{Grigory M. Zabortsev², \\ GMZaborcev@aogspi.ru}

\section{Vladislav A. Chernook ${ }^{2}$, VAChernook@aogspi.ru}

\author{
Afanasy A. Krestinin ${ }^{3}$, \\ AAKrestinin@aogspi.ru \\ 1 Novosibirsk State Technical University, \\ 20, Karl Marks avenue, Novosibirsk, 630073, Russia. \\ 2 Novosibirsk Branch of JSC «State Specialized Design Institute», \\ 2, B. Khmelnitsky street, Novosibirsk, 630075, Russia. \\ 3 JSC «State Specialized Design Institute», \\ 4, bld. 1A, Sharikopodshipnikovskaya street, Moscow, 115088, Russia.
}

Relevance. Quaternary (QII-IV) deposits are represented in geological structure of the investigated section within a depth of 20,0 m: cover, lake-glacial, fluvioglacial, sandy-argillaceous Dnieper-Moscow interglacial; Morainic clayey of the Moscow and Dnieper stages of glaciation; fluvioglacial sands of the Oxo-Dnieper interglaciation. These primers composing Paveltsevskaya tank farm pad (Dolgoprudny Moscow region) operating since 50-s of the XX century, are contaminated to a greater or lesser extent with petroleum products and heavy metals (lead, copper, zinc, cadmium, nickel). Owing to spills the oil products have leaked into the ground and reached the groundwater level $(5,5-6,5 \mathrm{~m})$ and formed in the areas of spreading lenses and interlayers of sandy soils of varying size in the clay thicker the floating lens of a mixture of gasoline and diesel fuel with output power of 0,2 up to 0,4 m. The significant pollution with oil products of the Bezymyannaya river water was found out. The river forms the pond before flowing into the Klyazma reservoir. The pond adjoins to the tank farm territory that can be related to discharge of oil product lenses into the pond.

The aim of the research is to develop an optimal scheme of remediation of oil-contaminated quaternary sand-clay soils forming the platform of the Paveltsevskaya tank farm based on the results of geological and engineering and environmental studies, including laboratory geochemical studies.

Methods: geotechnical studies of soils - drilling wells, laboratory geoecological studies of soil samples, monitoring of groundwater level, determination of the effect of biological preparations on degradation of oil products and humic preparations on the mobility of heavy metal ions in soils, ground waters of an overmoist aquifer in fluvioglacial piano-argillaceous sediments Dneprovsko-Moscow interglaciation and groundwater podmorennogo (nadyurskogo) aquifer during flyuvioglacial sandy deposits of the Oka-Dnepr Interglacial.

Results. The authors have proposed the scheme for complex remediation of contaminated soils at the site of the Paveltsevskaya tank farm, including pumping out lenses of petroleum products, immobilization of heavy metals in soils using humic preparations ("Energen Extra»), destruction of petroleum products by biological preparations (BIOIL-AA, FBUN SSC VB "Vector»; Novosibirsk) and installation of a hydraulic curtain (drainage). Implementation of the proposed scheme will allow extracting petroleum products, immobilizing heavy metals in the surface layer of the soil, reducing considerably the content of petroleum products in it and the flow of petroleum products from the aeration zone of the Paveltsevskaya tank farm into the basin of the Bezymyannaya river in the groundwater discharge zone.

\section{Key words:}

Tank farm, soil contamination, oil products, heavy metals, remediation, humic preparations, biological products, lenses of oil products, hydraulic curtain.

\section{REFERENCES}

1. Zakrutkin V.E., Kholodkov Yu.I., Podolsky A.D. Ecological consequences of oil storage in the interfluve of the Don and Sal rivers. Geoecology. Engineering geology. Hydrogeology. Geocryology, 2007, no. 6, pp. 506-517. In Rus.

2. Cheprasova A.S. Gidrogeologicheskie usloviya formirovaniya neftyanogo zagryazneniya $\mathrm{v}$ priust'evoy chasti doliny reki Tuapse (Severnyy Kavkaz) i puti uluchsheniya ekologicheskogo sostoyaniya geologicheskoy sredy. Avoereferat Dis. Kand. nauk [Hydrogeological conditions for the formation of oil pollution in the mouth of the Tuapse River valley (the North Caucasus) and ways to improve the ecological state of the geological environment. Cand. Diss. Abstract]. Tomsk, 2012. 21 p.

3. Goldberg V.M., Gazda S. Gidrogeologicheskie osnovy okhrany podzemnykh vod ot zagryazneniya [Hydrogeological basis for protec- tion of groundwater from pollution]. Moscow, Nedra Publ., 1984, $262 \mathrm{p}$.

4. Kirii 0.A. Ekologicheskaya otsenka ispol'zovaniya uglevodorodokislyayushchikh bakteriy pri bioremediatsii neftezagryaznennykh pochv i vod na yuge Rossii. Avtoreferat Dis. Kand. nauk [Ecological assessment of the use of hydrocarbon-oxidizing bacteria with bioremediation of oil-contaminated soil and water in the south of Russia. Cand. Diss. Abstract]. Rostov-on-Don, 2013. 20 p.

5. Chachina S.B., Boltunova S.V., Cherkashina N.V. Destruction of oil hydrocarbons using microbiological preparations «BaikalEm», «Tamir», «Vostok». Omsk Scientific Bulletin, 2015, no. 1, pp. 221-225. In Rus.

6. Chachina S.B., Lapochkin A.S. Influence of microbiological preparations "Baikal Em 1", «Tamir» and «Vostok» on the survival rate and number of earthworms Eisenia fetida in soil contamination 
with high concentrations of oil. International Journal of Applied and Fundamental Research, 2016, no. 6-3, pp. 512-514. In Rus.

7. Svarovskaya L.I., Altunina L.K., Elchaninova E.A. Biodegradation of aromatic compounds of oil polluting the soil. Protection of the environment in the oil and gas complex, 2015, no. 1, pp. 7-11. In Rus.

8. Krzhizh L., Pashkovskiy I.S. Oil polluted underground water: sanation or self-cleaning? Ecology production, 2007, no. 12, pp. 50-53. In Rus.

9. Seredin V.V. Sanitation of territories contaminated with oil and oil products. Geoecology, 2000, no. 6, pp. 525-540. In Rus.

10. PND F 16.1.41-04. Kolichestvenny khimicheskiy analiz pochv. Metodika vypolneniya izmereniy massovoy kontsentratsii nefte produktov v probakh pochv gravimetricheskim metodom [Quantitative chemical analysis of soils. Method for performing measurements of mass concentration of petroleum products in soil samples by gravimetric method]. Moscow, MPR RF publ., 2004. 13 p.

11. Odintsova T.A. Razrabotka tekhnologii identifikatsii i monitoringa neftyanykh zagryazneniy. Dis. Kand. nauk [Development of technology for identification and monitoring of oil pollution. Cand. Diss.]. Perm, 2010. 214 p.

12. Metodicheskie rekomendatsii po vyyavleniyu degradirovannykh zagryaznennykh zemel [Guidelines for identification of degraded and contaminated land]. (Approved. Roskomzemom 28.12.1994, the Ministry of Agriculture of the Russian Federation 26.01.1995, Ministry of Natural Resources of the Russian Federation 15.01.1995).

13. Siromlay T.I. Forms of compounds of lead, cadmium and zinc in soil of south Western Siberia. Messenger Orenburg state university, 2017, no. 12, pp. 26-29. In Rus.

14. Semenkov I.N. Formy nakhozhdeniia metallov v suglinistykh tun drovykh, taezhnkh, podtaezhnykh i lesostepnykh poshvenno-geokhimisheskikh katenakh. Avtoreferat Dis. Kand. nauk [Forms of finding metal in loamy, tundra, taiga and forest steppe soil-geochemical catens. Cand. Diss. Abstract]. Moscow, 2016. 24 p.

15. Ganeev I.G., Kulagin A.A. Remediation and Reclamation of Technogenically Degraded Lands. Vestnik Orenburg State University, 2009, no. 6, pp. 554-557. In Rus.

16. Radwan S.S., Al-Mailem D., El-Nemr I., Salamah S. Enhanced remediation of hydrocarbon contaminated desert soil fertilized with organic carbons. International Biodeterioration \& Biodegradation, 2000, vol. 46, no. 2, pp. 129-132.

17. Ayotamuno M.J., Kogbara R.B., Ogaji S.O.T., Probert S.D. Bioremediation of a crude-oil polluted agricultural-soil at Port Harcourt, Nigeria. Applied Energy, 2006, V. 83, no. 11, pp. 1249-1257.

18. Stevenson F.J. Organic matter reactions involving metal ions in soil. Ch. 16. Humus Chemistry: Genesis, Composition and Reactions. $2^{\text {nd }}$ ed. New York, John Wiley \& Sons, 1994.

19. Pompe S., Schmeide K., Bubner M., Geipel G., Heise K.H., Bernhard G., Nitsche H. Investigation of humic acid complexation behavior with uranyl ions using modified synthetic and natural humic acids. Radiochimica Acta, 2000, vol. 88, pp. 553-558.

20. Kim J.I., Czerwinski K.R. Complexation of Metal Ions with Humic Acid: Metal Ion Charge Neutralization Model. Radiochimica Acta, 1996, vol. 73, pp. 5-10.
21. Stevenson F.J. Humus Chemistry. $1^{\text {st }}$ ed. New York, John Wiley \& Sons, 1982.

22. Ognyanik N.S., Paramonova N.K., Briks A.L. Osnovy izucheniya zagryazneniya geologicheskoy sredy legkimi nefteproduktami [Basics of studying the pollution of the geological environment with light petroleum products]. Kiev, APN Publ., 2006. 278 p.

23. Gaffney J.S., Marley N.A., Clark S.B. Humic and Fulvic Acids. Isolation, Structure, and Environmental Role. ACS Symposium Series 651. Washington, DC, American Chemical Society, 1996. pp. 2-16.

24. Aiken G.R., McKnight D.M., Werhaw R.L., MacCarthy P. An Introduction to Humic Substances in Soil, Sediment and Water. $\mathrm{Hu}$ mic Substances in Soil, Sediment and Water. USA, John Wiley \& Sons, 1985.

25. Sachs S., Schmeide K., Brendler V., Křepelová A., Mibus J., Geipel G., Heise K.-H., Bernhard G. Synthesis and characterization of humic acids with specific functional properties. Investigation of the Complexation and the Migration of Actinides and Non-radioactive Substances with Humic Acids under Geogenic Conditions: Complexation of Humic Acids with Actinides in the Oxidation State IV Th, U, Np. Forschungszentrum Rossendorf, Institute of Radiochemistry, Wissenschaftlich-Technische Berichte. FZR 399, 2004, pp. 3-19.

26. Burlakovs J., Klavins M., Osinska L., Purmalis 0. The Impact of Humic Substances as Remediation Agents to the Speciation Forms of Metals in Soil. APCBEE Procedia 5, 2013, pp. 192-196.

27. Kaschl A., Chen Y. Interactions of Humic Substances with Trace Metals and Their Stimulatory Effects on Plant Growth technology. Use of Humic Substances to Remediate Polluted Environments: From Theory to Practice. Netherlands, Springer, 2005. pp. 83-113.

28. Ostrovsky Yu.V., Zabortsev G.M., Tsivelev V.V., Babushkin A.V., Ostrovsky D.Yu., Egorov N.B., Chegrintsev S.N. Use of coal humic preparations for the localization of uranium and mercury in liquid and solid industrial wastes of enterprises of the State Corporation «ROSATOM». Chemistry for Sustainable Development, 2016, vol. 24, no. 6, pp. 781-787. In Rus.

29. Grechischeva N.Yu., Perminova I.V., Meshcheryakov S.V. Prospectivity of the use of humic substances in cleaning technologies for oil-contaminated soils. Ecology and industry of Russia, 2016, no. 1, pp. 30-36. In Rus.

30. Lovley D.R., Coates J.D., Blunt-Harris E. L., Phillips E.J.P., Woodward J.C. Humic substances as electron acceptors for microbial respiration. Nature, 1996, no. 382, pp. 445-448.

31. Zhuravleva A.S., Labutova N.M., Andronov E.E. Influence of oil pollution on the microbiocenosis of soils adjacent to the oil storage. Ecological genetics, 2017, vol. 15, no. 1, pp. 60-68. In Rus.

32. Fedoseeva E.N., Zorin A.D., Zanozina V.F., Samsonova L.E. Migration of oil products from contaminated soil to a loose insulating layer of clean sand. Chemistry for Sustainable Development, 2014, vol. 22, no. 5, pp. 497-503. In Rus.

Received: 27 June 2018.

\section{Information about the authors}

Yury V. Ostrovsky, Dr. Sc., professor, Novosibirsk State Technical University, head of the Research Department, Novosibirsk Branch of JSC «State Specialized Design Institute».

Grigory M. Zabortsev, Cand. Sc., head of the Laboratory, the Research Department of the Novosibirsk Branch of JSC «State Specialized Design Institute».

Vladislav A. Chernook, Director, Novosibirsk Branch of JSC «State Specialized Design Institute».

Afanasy A. Krestinin, head of the Integrated Engineering Survey Department, JSC «State Specialized Design Institute». 